\title{
Reconciliation of halogen-induced ozone loss with the total-column ozone record
}

Article

Accepted Version

Shepherd, T. G., Plummer, D. A., Scinocca, J. F., Hegglin, M. I., Fioletov, V. E., Reader, M. C., Remsberg, E., von Clarmann, T. and Wang, H. J. (2014) Reconciliation of halogen-induced ozone loss with the total-column ozone record. Nature Geoscience, 7 (6). pp. 443-449. ISSN 1752-0908 doi: https://doi.org/10.1038/NGEO2155 Available at https://centaur.reading.ac.uk/36861/

It is advisable to refer to the publisher's version if you intend to cite from the work. See Guidance on citing.

Published version at: http://www.nature.com/ngeo/journal/v7/n6/full/ngeo2155.html

To link to this article DOI: http://dx.doi.org/10.1038/NGEO2155

Publisher: Nature Publishing Group

All outputs in CentAUR are protected by Intellectual Property Rights law, including copyright law. Copyright and IPR is retained by the creators or other copyright holders. Terms and conditions for use of this material are defined in the End User Agreement.

\section{www.reading.ac.uk/centaur}

\section{CentAUR}


Central Archive at the University of Reading

Reading's research outputs online 


\section{Reconciling halogen-induced ozone loss with the observed total ozone record}

3 T.G. Shepherd ${ }^{1 *}$, D.A. Plummer², J.F. Scinocca ${ }^{2}$, M.I. Hegglin ${ }^{1}$, V.E. Fioletov³ ${ }^{3}$ M.C.

$4 \quad$ Reader ${ }^{4}$, E. Remsberg 5 , T. von Clarmann 6 , H.J. Wang ${ }^{7}$

5

$6{ }^{1}$ Department of Meteorology, University of Reading, Reading RG6 6BB, U.K.

$7 \quad{ }^{2}$ Canadian Centre for Climate Modelling and Analysis, Environment Canada,

8 Victoria, British Columbia V8W 3V6, Canada

9 33Environment Canada, 4905 Dufferin St., Toronto, Ontario M3H 5T4, Canada

$10{ }^{4}$ School of Earth and Ocean Sciences, University of Victoria, P.O. Box 3055, Victoria,

11 British Columbia V8W 3P6, Canada

$12{ }^{5}$ National Aeronautics and Space Administration, Langley Research Center,

13 Hampton, VA 23681-2199 U.S.A.

$14{ }^{6}$ Institute for Meteorology and Climate Research, Karlsruhe Institute of Technology,

15 D-76021 Karlsruhe, Germany

$16{ }^{7}$ School of Earth and Atmospheric Sciences, Georgia Institute of Technology, Atlanta,

17 GA 30332-0340 U.S.A.

18

$19 *$ e-mail: theodore.shepherd@reading.ac.uk

20

21 Second revised version, March 2014

22 
1 The observed depletion of the ozone layer is attributed to anthropogenic

2 halogens, but the precision of this attribution is complicated by natural

3 dynamical variability (year-to-year meteorological variations) and by changes

4 in tropospheric ozone, leaving key aspects of the observed total ozone record

5 unexplained. These include inter-hemispheric differences in the response to

6 the Mount Pinatubo volcanic eruption, the lack of a decline prior to 1980 and

7 of any long-term decline in the tropics, and the apparent delay in ozone

8 recovery despite the significant decline of stratospheric halogen loading since

9 the late 1990s. Here we use a chemistry-climate model constrained by

10 observed meteorology to remove the effects of dynamical variability and to

11 estimate changes in tropospheric ozone. Ozone loss is shown to closely follow

12 stratospheric halogen loading, with pronounced enhancements in both

13 hemispheres following the volcanic eruptions of El Chichon and, especially,

14 Mount Pinatubo. Approximately $40 \%$ of the long-term non-volcanic loss is

15 found to have occurred by 1980 . Long-term ozone loss is found in the tropical

16 stratosphere, but is masked in the column by tropospheric increases. Ozone

17 loss has declined by over $10 \%$ since stratospheric halogen loading peaked in

18 the late 1990s, indicating that recovery of the ozone layer is well underway.

20 Anthropogenic emissions of halogenated (principally chlorine) species have led to

21 an observable depletion of the ozone layer ${ }^{1}$. Ozone depletion has been a matter of

22 wide public concern because of its implications for human and ecosystem health².

23 As a result of comprehensive controls on ozone-depleting substances, stratospheric 
1 chlorine loading peaked in the late 1990s and has been slowly declining since then ${ }^{1}$,

2 and is expected to continue to decline over the coming decades. Observed total

3 ozone levels have been stable since the late 1990s, rather than showing the expected

4 increase, but there is large year-to-year dynamical variability which can plausibly

5 obscure the onset of ozone recovery ${ }^{1,3}$.

7 Understanding the observed ozone record is important not only for confirming the

8 efficacy of the Montreal Protocol but also for testing the physical understanding of

9 ozone depletion. This becomes especially pertinent since ozone recovery will take

10 place in the presence of climate change, which affects the ozone layer through both

11 dynamical and chemical mechanisms ${ }^{4}$. For example, surface ultraviolet radiation

12 may not only be affected by halogen-induced ozone depletion but also by ozone

13 changes resulting from climate change ${ }^{5}$. From this perspective, it is important to

14 resolve several outstanding puzzles in the observed ozone record, e.g.: (i) Given that

15 stratospheric aerosol is expected to enhance halogen-induced ozone loss ${ }^{6}$, why was

16 there no decline in total ozone levels following the Mount Pinatubo eruption in the

17 Southern Hemisphere (SH), only in the Northern Hemisphere (NH) ${ }^{1}$ ? (ii) Why has

18 there been no observed decline in tropical total ozone ${ }^{1}$, in contrast with model

19 simulations $^{7}$ and in spite of observed ozone decreases in the stratosphere ${ }^{8}$ ? (iii) Why

20 did total ozone only decline after about $1980^{1}$, given that stratospheric halogen

21 loading reached about $40 \%$ of its maximum in $1980^{\circ}$ and again in contrast to model

22 simulations ${ }^{4}$ ? 
1 The combined ground-based and satellite record provides a reliable measure of

2 global total column ozone changes since $1964^{10}$. About $90 \%$ of total ozone resides in

3 the stratosphere, so it is generally assumed that the total ozone record can be

4 interpreted in terms of stratospheric changes ${ }^{1}$. Attribution of the observed

5 depletion of total ozone to anthropogenic halogens is complicated by internal

6 dynamical variability of the climate system, natural external forcing from solar

7 variability and volcanoes, and possible effects of climate change. Furthermore,

8 tropospheric ozone is believed to have increased through the $20^{\text {th }}$ century as a result

9 of increased anthropogenic emissions of ozone precursors ${ }^{11,12,13}$, and this could have

10 affected the total ozone record. Indeed the globally averaged tropospheric ozone

11 increases since pre-industrial times are estimated to be comparable in magnitude to

12 the halogen-induced stratospheric ozone decreases ${ }^{14}$. However, reliable

13 observational estimates of long-term changes in tropospheric ozone on a global

14 scale do not exist. ${ }^{12,13}$

\section{Combining models and measurements}

17 To quantify halogen-induced ozone loss in a changing and variable atmosphere, it is

18 necessary to remove the effects of those changes and variations. This is generally

19 done statistically ${ }^{15}$, but not all atmospheric variability is represented in statistical

20 models, the relationships between proxies and ozone are only approximate, and the

21 parameterized effects on ozone are not necessarily separable. Furthermore the

22 effects of secular changes such as climate change or changes in tropospheric ozone

23 are difficult to deal with in such an approach. As a result, statistical estimates of 
1 halogen-induced loss can depend sensitively on the period chosen and the statistical

2 model used ${ }^{16}$, especially in the tropics and $\mathrm{NH}$ where ozone depletion is

3 comparatively small relative to the $\mathrm{SH}$, and the effect of other factors comparatively

4 large.

5

6 However it is well known that stratospheric ozone is slaved to the meteorology,

7 once the source gases are prescribed ${ }^{17}$. Furthermore, stratospheric ozone chemistry

8 is well established, with generally good agreement concerning chemical

9 mechanisms between chemistry-climate models and measurements ${ }^{18}$. (See Methods

10 for discussion of the model used here.) This means that the effect of chemical

11 perturbations, such as halogen loading, on ozone changes can be determined by

12 reproducing the ozone changes with a chemistry-climate model driven by the

13 observed meteorology, using known chemical processes, and then calculating the

14 difference in ozone between simulations performed with and without the chemical

15 perturbation ${ }^{19}$.

17 The success of such an approach relies on being able to reproduce the past changes,

18 which in turn relies on having a sufficiently good estimate of the past meteorology.

19 Previous attempts have had difficulty reproducing the past ozone changes because

20 of deficiencies in the meteorological reanalyses used to drive the model ${ }^{19}$.

21 Developments in data assimilation have recently led to much more stable

22 reanalyses. We use the ERA-Interim reanalysis ${ }^{20}$ covering the period 1979-2009 to

23 drive a chemistry-climate model (see Methods). The ERA-40 reanalysis ${ }^{21}$ is used to 
1 examine the pre-1979 period. This introduces an inhomogeneity in the modelled

2 timeseries, which is bridged using the run with constant ozone depleting substances

3 (cODS) as a transfer standard (see Supplementary Information). The quantification

4 of halogen-induced ozone loss is insensitive to this bridging, since it is computed

5 from the differences between the two simulations.

6

7 In the absence of reliable observational estimates of long-term changes in global

8 tropospheric ozone, estimates are generally derived from models driven by

9 historical estimates of ozone precursor emissions 9 . Such model-based estimates of

10 tropospheric ozone changes are evidently rather uncertain, in part because the

11 emissions are not known very precisely. However, by including those changes

12 within the same modelling framework as that used to simulate the stratospheric

13 ozone changes, a self-consistent estimate of total ozone changes is obtained.

14 Moreover the stratospheric component of those changes can be compared with the

15 more limited observational record available from limb-sounding satellite

16 instruments ${ }^{22}$. When considered together with the total ozone measurements, this

17 allows inferences to be drawn about the realism of the modelled tropospheric ozone

18 changes, and the contributions of the various factors to the observed total ozone

19 record.

20

21 Understanding the observed total ozone record

22 Figure 1 shows timeseries of total ozone anomalies, relative to the 1964-1978

23 reference period, for the near-global mean, $\mathrm{SH}$ and $\mathrm{NH}$ midlatitudes, and tropics. In 
1 general the simulated total ozone including effects of ODS changes (ODS simulation,

2 black) follows the observations (orange) closely, in both year-to-year variability and

3 long-term changes. This level of agreement provides confidence that these

4 simulations can be used to remove the effects of dynamical variability and quantify

5 the halogen-induced ozone loss. Apart from some isolated periods where the

6 variability does not match (mid 1970s for NH midlatitudes, around 1970 for the

7 tropics), which likely indicate issues with the ERA-40 reanalysis, the main

8 discrepancy is that the model under-represents the extent of the long-term decline

9 in NH midlatitudes. The positive model bias in NH midlatitudes is already present in

10 the early 1980 s and is fairly stable through to about 2005. This suggests that it is not

11 the result of too little halogen-induced loss, since any such bias would follow the

12 stratospheric halogen loading which peaked in the late 1990s.

14 Since springtime polar ozone loss can influence midlatitude ozone ${ }^{23}$, springtime

15 polar total ozone is shown for completeness in Figure 2. Whilst the long-term

16 decline is well simulated in the Arctic, the model underestimates the long-term

17 decline in the Antarctic by about 30 DU, or roughly $25 \%$ of the total observed

18 depletion. This might be due to the fact the model does not include any

19 representation of Nitric Acid Trihydrate (NAT) polar stratospheric clouds (PSCs) or

20 the associated denitrification ${ }^{24}$, which has been argued to have a negligible vortex-

21 wide effect in the Arctic ${ }^{25}$ but to account for about $25 \%$ of the depth of the Antarctic

22 ozone hole ${ }^{26}$. The absence of VSLS bromine in the model could also contribute to the

23 underestimation of Antarctic ozone loss. Since approximately $50 \%$ of the observed 
1 SH midlatitude annual-mean ozone depletion is believed to result from the ozone

2 hole ${ }^{23}$, a $25 \%$ underestimation of Antarctic depletion implies a 10-15\%

3 underestimation of SH midlatitude depletion. As will be seen (e.g. Table 1), this

4 corresponds to the actual extent of underestimation found here (about 11\%) but in

5 any case is well within the statistical uncertainties of our quantification.

7 The blue curves in Figure 1 (and Figure 2) show the cODS simulation, which exhibits

8 the same interannual variability as the ODS simulation, as well as a long-term

9 increase in total ozone up to about 1980 in $\mathrm{NH}$ midlatitudes, and a somewhat

10 smaller increase up to the mid 1980s in the tropics (and thus also in near-global

11 ozone). The timing, magnitude and hemispheric asymmetry of these increases is

12 consistent with increases in tropospheric ozone simulated by chemistry-climate

13 models forced by historical estimates of tropospheric ozone precursor emissions ${ }^{27}$,

14 and Table 1 confirms that the increases in the cODS simulation primarily occur in

15 the troposphere.

17 The ODS-induced ozone loss is determined from the difference between the blue

18 and black curves in Figure 1 and shows, as expected, that the observed long-term

19 ozone decline is attributable to ODS changes. The difference is shown explicitly in

20 Figure 3, together with the modelled stratospheric halogen loading, represented by

21 Equivalent Stratospheric Chlorine (ESC) ${ }^{7}$. In contrast to the large year-to-year

22 variability in ozone itself (Figure 1), the ODS-induced ozone loss is a much smoother

23 function of time and follows the halogen loading closely, modulated by volcanic 
1 aerosol in both hemispheres. Although the full nonlinearity of known stratospheric

2 ozone chemistry is represented in the model, the approximately linear dependence

3 of ozone loss on ESC found here, together with the very close match between ESC

4 and Equivalent Effective Stratospheric Chlorine (EESC) ${ }^{28}$ which is based on

5 tropospheric halocarbon abundances, supports the use of EESC as an explanatory

6 variable in statistical analyses of global ozone changes ${ }^{29}$. However Figure 3 also

7 emphasizes the need to include volcanic enhancements in both hemispheres. The

8 ozone loss is seen to be greater (by $50 \%$ ) in the $\mathrm{SH}$ than in the $\mathrm{NH}$, to be enhanced

9 by volcanic aerosol by both El Chichon and, especially, Mount Pinatubo in both

10 hemispheres, to have reached approximately $40 \%$ of its maximum (neglecting years

11 influenced by volcanoes) by 1980 , and to have occurred in the tropics. All this is

12 consistent with physical understanding, but only the first of these conclusions is

13 evident from the total ozone record (Figure 1) alone. The percentage of the long-

14 term non-volcanic ODS-induced loss incurred by 1980 is quantified in Figure 3 by

15 the $1978-1982$ and $1996-2002$ mean values, and is $49 \pm 16 \%$ in the tropics, $43 \pm 15 \%$

16 in NH midlatitudes, $35 \pm 8 \%$ in SH midlatitudes, and $42 \pm 12 \%$ globally (see

17 Supplementary Information for calculation of 95\% confidence intervals).

19 The ODS-induced ozone loss computed here does not include possible ozone

20 changes induced by dynamical feedbacks. Any such changes would be apparent in

21 the cODS simulation, which however exhibits no long-term change in stratospheric

22 ozone in any region (Table 1). 
1 The interannual variability in total ozone seen in Figure 1 can lead to significant

2 deviations from the ODS-induced behaviour. The strong dip in SH midlatitude ozone

3 in the mid-1980s is also seen in the cODS simulation, showing that it resulted from

4 meteorological variability. The same conclusion applies to the large increase from

5 the late 1990s to the mid-2000s (see also Refs. 30,31). The lack of a decrease in SH

6 midlatitude ozone following the Mount Pinatubo volcanic eruption in 1991 is

7 explained by the fact that chemical loss was masked by a dynamically driven

8 increase, evident in the cODS simulation (see also Refs. 32,33). Although total ozone

9 anomalies are, within the year-to-year variability, fairly stable in all regions since

10 halogen loading peaked in the late $1990 s^{1}$, the ODS-induced loss in Figure 3 shows a

11 decline from $1996-2002$ to $2006-2009$ of $15 \pm 6 \%$ in the tropics, $11 \pm 9 \%$ in $\mathrm{NH}$

12 midlatitudes, $12 \pm 7 \%$ in SH midlatitudes, and $13 \pm 6 \%$ globally, all of which are

13 consistent with the observed decline in stratospheric halogen loading over this

14 period $^{1}$.

16 In principle there may be a chemical component to the interannual variability, since

17 dynamical variations affect lower stratosphere ozone and temperature in the same

18 way $^{34}$, e.g. a stronger poleward mass flux implies more extratropical ozone from

19 enhanced transport but also higher temperatures, which reduce ODS-induced ozone

20 loss associated with polar processes. This effect is quantified by the ratio of total

21 ozone anomalies in the ODS to the cODS simulation, during a period of stable

22 halogen loading (Figure 4). A slope exceeding unity indicates chemical amplification

23 of dynamically induced ozone variability. Such an effect is clearly seen in springtime 
1 polar-cap averaged ozone levels in the Antarctic, with a much weaker effect

2 apparent in Arctic springtime. However little if any effect is found at midlatitudes.

4 In order to reconcile the estimates of ODS-induced long-term ozone loss with the

5 observed total ozone record, it is necessary to consider not only meteorological

6 variability but also the effect of the tropospheric ozone increases apparent in the

7 cODS simulation (blue curves in Figure 1). Although there are no reliable

8 observational estimates of global tropospheric ozone changes, global observations

9 of stratospheric ozone are available from limb-sounding satellite instruments since

10 about $1980^{22}$ and can be used as an independent test of model performance. Figure

115 shows timeseries of tropospheric and stratospheric partial columns from the ODS

12 simulation, together with the observed stratospheric partial columns. The reference

13 level for the observed anomalies is defined to match the mean value of the modelled

14 anomalies during the MIPAS period (2005-2009), when the observational sampling

15 is most dense, with no further adjustment applied; hence the changes in the

16 observed anomalies relative to MIPAS arise purely from the observations. The

17 modelled stratospheric timeseries are seen to match the monthly-mean variations

18 in the MIPAS record extremely well, providing confidence in the simulated

19 stratospheric partial columns. Good agreement is also found with the SAGE II

20 record, except in the tropics in the late part of the record. Although the earliest

21 estimates from LIMS and SAGE I are noisy, on the whole the comparison with

22 observations suggests that the simulated changes in stratospheric ozone are

23 realistic in all three regions. 
2 The simulated long-term changes in both stratospheric and tropospheric ozone,

3 between the reference period 1964-1978 and the period 1996-2002 of maximum

4 (non-volcanic) ODS-induced ozone loss, are shown in Table 1 for the ODS and cODS

5 simulations and for their difference. From Table 1 and Figure 5 the following

6 conclusions can be drawn. In SH midlatitudes, the long-term decline in the ODS

7 simulation matches the observed total ozone decline of about 19 DU (6\%) and

8 approximately equals the ODS-induced ozone loss. There is a small non-ODS

9 induced increase in tropospheric ozone (3 DU) that is offset by an ODS-induced

10 tropospheric ozone decline, leading to very little net change in tropospheric ozone.

12 In NH midlatitudes, the long-term decline in the ODS simulation of 7 DU significantly

13 under-estimates the observed total ozone decline of $12 \mathrm{DU}(3 \%)$. Because the

14 modelled stratospheric decline of $12 \mathrm{DU}$ is consistent with the observed

15 stratospheric decline, this implies that the modelled tropospheric increase of 5 DU

16 over this period is too large, hence that the assumed emissions of tropospheric

17 ozone precursors increase too much during this period. This is consistent with a

18 general high bias in present-day NH tropospheric ozone in models ${ }^{35}$. Pre-1980

19 ozone loss was primarily obscured by dynamical variability (note the lack of a

20 discernible trend before 1980 in the modelled stratospheric ozone in Fig. 5b), but

21 also was likely offset to some extent by increases in tropospheric ozone. 
1 In the tropics, the barely discernible long-term decline in total column ozone in the

2 ODS simulation matches the observations, whilst the decline of 5 DU in the

3 stratosphere, which is attributable to ODS, also matches the observations. Although

4 there is no way of independently confirming the modelled increase of $3 \mathrm{DU}$ in

5 tropospheric ozone, this result shows that the observed total ozone record in the

6 tropics is not necessarily incompatible with observed estimates of a stratospheric

7 ozone decrease, potentially resolving the apparent discrepancy between the two

8 records ${ }^{1,8}$. The implication is that the ODS-induced ozone decline in the tropics,

9 which is expected from models ${ }^{7}$, was largely masked by increases in tropospheric

10 ozone.

11

\section{Conclusions}

13 A chemistry-climate model, representing the combined effects of tropospheric and

14 stratospheric ozone chemistry and driven by observed meteorology, has been used

15 to quantify halogen-induced ozone loss and its contribution to the observed total

16 ozone record. Constraining the model by the observed meteorology allows removal

17 of the effects of dynamical variability in a more precise way than is possible using

18 purely statistical methods, while modelling tropospheric ozone together with

19 stratospheric ozone allows investigation of the contribution of tropospheric ozone

20 changes to the observed total ozone record. This approach resolves several

21 outstanding puzzles in that record and allows the identification of the onset of total

22 ozone recovery. 
1 Year-to-year variability in ozone mainly arises from meteorological variability

2 together with enhancement of halogen-induced loss from volcanic aerosol loading.

3 The latter is seen to arise in both hemispheres, especially after the eruption of

4 Mount Pinatubo when halogen loading was high, but the chemical impact of Mount

5 Pinatubo on SH midlatitude total ozone was masked by dynamical variability.

6 Variability obscured the fact that approximately $40 \%$ of the (non-volcanic) long-

7 term ozone loss had already occurred by 1980 . Following the peak stratospheric

8 halogen loading in the late 1990s, variability has similarly obscured a clearly

9 identifiable decline in ODS-induced ozone loss of more than $10 \%$, consistent with

10 the decline in halogen loading, indicating that recovery of the ozone layer is well

11 underway.

13 Although emissions of tropospheric ozone precursors are somewhat uncertain and

14 there are no reliable estimates of global changes in tropospheric ozone, the realism

15 of the model simulation of tropospheric ozone changes can be assessed using the

16 independent constraints provided by the observed global record of total ozone

17 (since 1964) and of stratospheric ozone (since 1979). Considered together with the

18 model simulations, these records suggest that the lack of an observed decrease in

19 tropical total ozone is because increases in tropospheric ozone masked the

20 stratospheric ODS-induced decline, reconciling the apparent discrepancy between

21 observed changes in stratospheric and total column tropical ozone. Detailed

22 comparison of nudged simulations as used here with tropospheric ozone

23 measurements may help resolve the conflicting trends apparent in those data sets ${ }^{1}$. 
2 These results show the value of using models and observations together to

3 understand the observed total ozone record, allowing much stronger conclusions

4 than can be obtained from models or observations separately.

\section{Methods}

7 Model simulations. The chemistry-climate model is a version of the Canadian

8 Middle Atmosphere Model (CMAM) ${ }^{36}$, with 71 vertical levels spanning the surface to

9 about $100 \mathrm{~km}$ at a horizontal spectral resolution of $\mathrm{T} 47$, corresponding to a $3.75^{\circ}$

10 horizontal grid. Extensive evaluation against observations has shown that CMAM is

11 one of the best performing models in terms of stratospheric transport and

12 chemistry ${ }^{1,18}$. The chemical kinetics are based on JPL-2006 ${ }^{37}$. Stratospheric source

13 gases (halocarbons, $\mathrm{N}_{2} \mathrm{O}$ and $\mathrm{CH}_{4}$ ) are prescribed as time-varying tropospheric

14 concentrations, except in the cODS simulation where the halocarbons (but not $\mathrm{N}_{2} \mathrm{O}$

15 or $\mathrm{CH}_{4}$ ) are held constant at 1960s values. The halocarbons in the ODS simulation

16 follow the adjusted A1 scenario ${ }^{23}$, and do not include any additional bromine or

17 chlorine from VSLS. The absence of halogenated VSLS could lead to an

18 underestimation of ODS-induced ozone loss in polar regions and in midlatitudes

19 during conditions of enhanced aerosol loading ${ }^{23}$. The greenhouse gases evolve

20 following the SRES A1B scenario ${ }^{38}$.

22 This version of CMAM includes a representation of $\mathrm{CH}_{4}-\mathrm{NO}_{\mathrm{x}}$ chemistry within the

23 troposphere, and was included in the Atmospheric Chemistry and Climate Model 
1 Intercomparison Project (ACCMIP). Tropospheric chemical forcings were as

2 specified in ACCMIP27. Although the model neglects non-methane volatile organic

3 compounds (NMVOCs), it produces present-day tropospheric ozone levels that

4 compare well with observations, and both pre-industrial and present-day

5 tropospheric ozone levels fall well within the ACCMIP model distribution ${ }^{35}$. This is

6 consistent with model sensitivity studies which attribute most of the increase in

7 tropospheric ozone since pre-industrial times to the increase in $\mathrm{CH}_{4}$ and $\mathrm{NO}_{\mathrm{x}}$, with

8 only a minor contribution from NMVOCs ${ }^{39}$. Thus the model is well designed for

9 investigating changes in the large-scale distributions of tropospheric and

10 stratospheric ozone.

11

12 This version of CMAM is run in a 'specified dynamics' mode, where the

13 meteorological fields (winds and temperature, but not water vapour) at altitudes

14 below $1 \mathrm{hPa}$ are nudged (i.e. relaxed) towards a meteorological reanalysis, with the

15 nudging tapering off rapidly for altitudes above $10 \mathrm{hPa}$ (e.g. nudging strength at 5

$16 \mathrm{hPa}$ is $20 \%$ of that at $10 \mathrm{hPa}$ ). Details of the nudging procedure are provided in Ref.

1740 , except that here the zonal-mean nudging was also tapered off above $10 \mathrm{hPa}$.

18 Prior to 1979 , the model was nudged to the ERA-40 reanalysis ${ }^{21}$ and after 1979 to

19 ERA-Interim ${ }^{20}$. This introduces an inhomogeneity into the nudged data set across

20 the 1979 transition, which is dealt with as discussed in the Supplementary

21 Information.

22

23 The ozone in the nudged model cannot be expected to follow the observed record 
1 exactly, because of uncertainties both in the ozone observations and in the

2 reanalysis used to drive the model, the fact the model will not follow the reanalysis

3 exactly because of the nudging methodology, and model limitations including

4 transport, spatial resolution of low temperature regions, and treatment of chemistry

5 (including PSCs).

6

7 Observational data sets. The total column ozone data set is an update of that in

8 Ref. 10, which has been widely used in recent WMO/UNEP Ozone Assessments ${ }^{1,23}$.

9 Zonal-mean total ozone time series are obtained from ground-based measurements

10 by Dobson and Brewer spectrophotometers and filter ozonometers for the period

11 from 1964 to 2010, using satellite measurements to correct for climatological

12 sampling biases in the ground-based network. The data set has been shown to

13 successfully reproduce seasonal means and averages over longer periods on the

14 global scale ${ }^{10}$ as well as springtime variations in polar regions ${ }^{41}$. Because solar

15 variability was not included in the model simulations, its effects were removed

16 statistically from the observational timeseries.

18 The stratospheric partial column data sets are calculated from the monthly zonal

19 mean ozone climatologies provided by the SPARC Data Initiative ${ }^{22}$, by integrating

20 the ozone abundances above the zonal mean thermal tropopause, which is

21 calculated from the 3D model temperature fields using the WMO standard

22 tropopause definition ${ }^{42}$ and interpolated onto the SPARC Data Initiative latitude

23 grid. The instruments considered here are LIMS $^{43}$, SAGE I44, SAGE II ${ }^{45}$, and MIPAS ${ }^{46}$. 
1 No attempt is made to remove the effect of the solar cycle from these observations

2 because of the gaps in the record. Note that MIPAS data are only used after January

32005 (version V5R_03_220), when the instrument switched measurement mode

4 and subsequently showed excellent agreement with SAGE II. An exception to this

5 agreement is the tropical lower stratosphere, where MIPAS compares well to most

6 of the other SPARC Data Initiative climatologies, but not to SAGE II which is biased

7 low in this region ${ }^{22}$. The latter finding offers a potential explanation of why the

8 stratospheric partial column ozone from SAGE II shows slightly more negative

9 anomalies than the ODS simulation in the tropics in the late 1990s and early 2000s

10 (Figure 5c). Note also that the LIMS version 6 data used here have a known low bias

11 in the tropical lower stratosphere ${ }^{47}$, which may affect the stratospheric partial

12 columns in the tropics.

\section{References}

16 1. World Meteorological Organization, Scientific Assessment of Ozone Depletion: 2010,

17 Global Ozone Research and Monitoring Project Report 52 (WMO, 2011).

18 2. United Nations Environment Programme, Environmental Effects of Ozone

19 Depletion: 2010 Assessment (UNEP, 2010).

20 3. Kiesewetter, G., Sinnhuber, B. M., Weber, M. \& Burrows, J. P. Attribution of

21 stratospheric ozone trends to chemistry and transport: a modelling study. Atmos.

22 Chem. Phys. 24, 12073-12089 (2010). 
1 4. Shepherd, T. G. Dynamics, stratospheric ozone, and climate change. Atmos.-Ocean

2 46, 371-392 (2008).

3 5. Hegglin, M. I. \& Shepherd, T. G. Large climate-induced changes in UV index and

4 stratosphere-to-troposphere ozone flux. Nature Geosci. 2, 687-691 (2009).

5 6. Solomon, S. et al. The role of aerosol variations in anthropogenic ozone depletion

6 at northern midlatitudes. J. Geophys. Res. 101, 6713-6727 (1996).

7 7. Eyring, V. et al. Multi-model projections of stratospheric ozone in the $21^{\text {st }}$ century.

8 J. Geophys. Res. 112, D16303, doi:10.1029/2006JD008332 (2007).

9 8. Randel, W. J. \& Wu, F. A stratospheric ozone profile data set for 1979-2005:

10 Variability, trends, and comparisons with column ozone data. J. Geophys. Res. 112,

11 D06313, doi:10.1029/2006JD007339 (2007).

12 9. Cionni, I. et al. Ozone database in support of CMIP5 simulations: results and

13 corresponding radiative forcing. Atmos. Chem. Phys. 11, 11267-11292 (2011).

14 10. Fioletov, V. E., Bodeker, G. E., Miller, A. J., McPeters, R. D. \& Stolarski, R. Global

15 and zonal total ozone variations estimated from ground based and satellite

16 measurements: 1964-2000. J. Geophys. Res. 107, 4647, doi:10.1029/2001JD001350

17 (2002).

18 11. Lamarque, J.-F. et al. Tropospheric ozone evolution between 1890 and 1990. J.

19 Geophys. Res. 110, D08304, doi:10.1029/2004JD005537 (2005).

20 12. Marenco, A., Gouget, H., Nédélec, P., Pagés, J.-P. \& Karcher, F. Evidence of a long-

21 term increase in tropospheric ozone from Pic du Midi data series: Consequences:

22 Positive radiative forcing. J. Geophys. Res., 99, 16617-16632 (1994). 
1 13. Parrish, D. D. et al. Long-term changes in lower tropospheric baseline ozone

2 concentrations at northern mid-latitudes. Atmos. Chem. Phys., 12, 11485-11504

3 (2012).

4 14. Reader, M. C., Plummer, D. A., Scinocca, J. F. \& Shepherd, T. G. Contributions to

5 20th century total column ozone change from halocarbons, tropospheric ozone

6 precursors, and climate change. Geophys. Res. Lett. 40, 6276-6281 (2013).

7 15. Mäder, J. A. et al. Statistical modeling of total ozone: Selection of appropriate

8 explanatory variables. J. Geophys. Res., 112, D11108, doi:10.1029/2006JD007694

9 (2007).

10 16. Vyushin, D. I., Fioletov, V. E. \& Shepherd, T. G. Impact of long-range correlations

11 on trend detection in total ozone. J. Geophys. Res. 112, D14307,

12 doi:10.1029/2006JD008168 (2007).

13 17. Hadjinicolaou, P., Pyle, J. A., Chipperfield, M. P. \& Kettleborough, J. A. Effect of

14 interannual meteorological variability on mid-latitude 03. Geophys. Res. Lett. 24,

$15 \quad 2993-2996$ (1997).

16 18. Stratospheric Processes And their Role in Climate, SPARC Report on the

17 Evaluation of Chemistry-Climate Models, V. Eyring, T. G. Shepherd, D. W. Waugh

18 (Eds.), SPARC Report No. 5, WCRP-132, WMO/TD-No. 1526 (SPARC CCMVal, 2010).

19 19. Feng, W., Chipperfield, M. P., Dorf, M., Pfeilsticker, K. \& Ricaud, P. Mid-latitude

20 ozone changes: studies with a 3-D CTM forced by ERA-40 analyses. Atmos. Chem.

21 Phys., 9, 2357-2369 (2007).

22 20. Dee, D. P. et al. The ERA-Interim reanalysis: configuration and performance of

23 the data assimilation system. Q. J. Roy. Meteor. Soc. 656, 553-597 (2011). 
1 21. Uppala, S. M. et al. The ERA-40 re-analysis. Q. J. Roy. Meteor. Soc. 612, 2961-3012

2 (2005).

3 22. Tegtmeier, S. et al. The SPARC Data Initiative: A comparison of ozone

4 climatologies from international limb satellite sounders. J. Geophys. Res. 118,

$5 \quad 12,229-12,247(2013)$.

6 23. World Meteorological Organization, Scientific Assessment of Ozone Depletion:

7 2006, Global Ozone Research and Monitoring Project Report 50 (WMO, 2007).

8 24. Plummer, D. A., Scinocca, J. F., Shepherd, T. G., Reader, M. C. \& Jonsson, A. I.

9 Quantifying the contributions to stratospheric ozone changes from ozone depleting

10 substances and greenhouse gases. Atmos. Chem. Phys. 10, 8803-8920 (2010).

11 25. Wegner, T. et al. Heterogeneous chlorine activation on stratospheric aerosols

12 and clouds in the Arctic polar vortex. Atmos. Chem. Phys. 12, 11095-11106 (2012).

13 26. Portmann, R. W. et al. Role of aerosol variations in anthropogenic ozone

14 depletion in the polar regions. J. Geophys. Res. 101, 22991-23006 (1996).

15 27. Lamarque, J.-F. et al. Historical (1850-2000) gridded anthropogenic and biomass

16 burning emissions of reactive gases and aerosols: Methodology and application.

17 Atmos. Chem. Phys. 10, 7017-7039 (2010).

18 28. Newman, P. A., Daniel, J. S., Waugh, D. W. \& Nash, E.R. A new formulation of

19 equivalent effective stratospheric chlorine (EESC). Atmos. Chem. Phys. 7, 4537-4552

20 (2007).

21 29. Stolarski, R. S., Douglass, A. R., Steensrud, S. \& Pawson, S. Trends in stratospheric

22 ozone: Lessons learned from a 3D Chemical Transport Model. J. Atmos. Sci. 63, 23 1029-1041 (2006). 
1 30. Hadjinicolaou, P., Pyle, J. A. \& Harris, N. R. P. The recent turnaround in

2 stratospheric ozone over northern middle latitudes: A dynamical modeling

3 perspective. Geophys. Res. Lett. 32, 12821, doi:10.1029/2005GL022476 (2005).

4 31. Dhomse, S., Weber, M., Wohltmann, I., Rex, M. \& Burrows, J. P. On the possible

5 causes of recent increases in northern hemispheric total ozone from a statistical

6 analysis of satellite data from 1979 to 2003. Atmos. Chem. Phys. 6, 1165-1180

7 (2006).

8 32. Telford, P., Braesicke, P., Morgenstern, O. \& Pyle, J. Reassessment of causes of

9 ozone column variability following the eruption of Mount Pinatubo using a nudged

10 CCM. Atmos. Chem. Phys. 9, 4251-4260 (2009).

11 33. Poberaj, C. S., Staehelin, J. \& Brunner, D. Missing stratospheric ozone decrease at

12 Southern Hemisphere middle latitudes after Mount Pinatubo: A dynamical

13 perspective. J. Atmos. Sci. 68, 1922-1945 (2011).

14 34. Randel, W. J. \& Cobb, J. B. Coherent variations of monthly mean total ozone and

15 lower stratospheric temperature. J. Geophys. Res. 99, 5433-5447 (1994).

16 35. Young, P. J. et al. Pre-industrial to end 21st century projections of tropospheric

17 ozone from the Atmospheric Chemistry and Climate Model Intercomparison Project

18 (ACCMIP). Atmos. Chem. Phys. 13, 2063-2090 (2013).

19 36. Scinocca, J., McFarlane, N. A., Lazare, M., Li, J. \& Plummer, D. Technical

20 Note: The CCCma third generation AGCM and its extension into the middle

21 atmosphere. Atmos. Chem. Phys. 8, 7055-7074 (2008). 
1 37. Sander, S. P. et al. Chemical Kinetics and Photochemical Data for Use in

2 Atmospheric Studies, Evaluation Number 15. JPL Publication 06-2 (Jet Propulsion

3 Laboratory, Pasadena, 2006).

4 38. Intergovernmental Panel on Climate Change. Special Report on Emissions

5 Scenarios: A Special Report of Working Group III of the Intergovernmental Panel

6 on Climate Change (Cambridge Univ. Press, 2000).

7 39. Shindell, D. T. et al. Improved attribution of climate forcing to emissions. Science

$8 \quad 326,716-718(2009)$.

9 40. McLandress, C., Scinocca, J. F., Shepherd, T. G., Reader, M. C. \& Manney, G. L.

10 Dynamical control of the mesosphere by orographic and non-orographic gravity

11 wave drag during the extended northern winters of 2006 and 2009. J. Atmos. Sci. 70,

$12 \quad$ 2152-2169 (2013).

13 41. Weber, M. et al. Stratospheric Ozone, in "State of the Climate in 2011". Bull. Amer.

14 Meteor. Soc. 93 (7), S46-S49 (2012).

15 42. World Meteorological Organization, Meteorology - A three-dimensional science.

16 WMO Bull, 6, 134-138 (WMO, 1957).

17 43. Remsberg, E. et al. On the quality of the Nimbus 7 LIMS version 6 ozone for

18 studies of the middle atmosphere. J. Quant. Spectros. Rad. Transf. 105, 492-1031

19 (2007).

20 44. Wang, H. J., Cunnold, D. M. \& Bao, X. A critical analysis of Stratospheric Aerosol

21 and Gas Experiment ozone trends. J. Geophys. Res. 101, 12495-12514 (1996). 
1 45. Wang, H. J., Cunnold, D. M., Thomason, L. W., Zawodny, J. M. \& Bodeker, G. E.

2 Assessment of SAGE version 6.1 ozone data quality. J. Geophys. Res. 107, 4691,

3 doi:10.1029/2002JD002418 (2002).

4 46. Von Clarmann, T. et al. Retrieval of temperature, $\mathrm{H}_{2} \mathrm{O}, \mathrm{O}_{3}, \mathrm{HNO}_{3}, \mathrm{CH}_{4}, \mathrm{~N}_{2} \mathrm{O}$,

$5 \mathrm{ClONO}_{2}$ and $\mathrm{ClO}$ from MIPAS reduced resolution nominal mode limb emission

6 measurements. Atmos. Meas. Techn. 2, 159-175 (2009).

7 47. Remsberg, E. et al. On the inclusion of Limb Infrared Monitor of the Stratosphere

8 version 6 ozone in a data assimilation system. J. Geophys. Res. 118, 7982-8000,

9 doi:10.1002/jgrd.50566 (2013).

10 48. Stolarski, R. S. \& Frith, S. M. Search for evidence of trend slow-down in the long-

11 term TOMS/SBUV total ozone data record: the importance of instrument drift

12 uncertainty. Atmos. Chem. Phys. 6, 4057-4065 (2006).

13 49. Fioletov, V. E. \& Shepherd, T.G. Seasonal persistence of midlatitude total ozone

14 anomalies. Geophys. Res. Lett. 30, 1417, doi:10.1029/2002GL016739 (2003).

15

16 Correspondence and request for materials should be addressed to T.G.S.

17

\section{Acknowledgements}

19 This work was funded by the Canadian Space Agency through the CMAM20 project,

20 with additional institutional support from the Canadian Centre for Climate

21 Modelling and Analysis who provided the model code and supercomputing time. 


\section{Author contributions}

2 T.G.S. conceived the experiment, interpreted the results, and wrote the paper; D.A.P.

3 performed the diagnostic analysis and devised the bias-correction procedure; J.F.S.

4 devised and implemented the nudging procedure used to perform the experiments;

5 M.I.H. performed the analysis of stratospheric partial column ozone and contributed

6 to the writing; V.E.F. processed and provided the ground-based data and

7 contributed to the interpretation; M.C.R. performed the simulations; and E.R., T.v.C.

8 and H.J.W. processed and provided the LIMS, MIPAS and SAGE data, respectively.

9

\section{Additional information}

11 Supplementary information is provided.

12

\section{Competing financial interests}

14 The authors declare no competing financial interests.

15

16 


\section{Figure legends}

2 Figure 1 | Time evolution of global total ozone. Deseasonalized total ozone

3 anomalies relative to the 1964-1978 reference period for the model simulation with

4 changing ODS abundances (ODS, black), the model simulation with ODS abundances

5 held constant at 1960s values (cODS, blue), and ground-based observations

6 (orange), for different latitude bands. The model simulations are not plotted across

7 the ERA-40/ERA-Interim transition (see Supplementary Information). The

8 correlation between the ODS simulation and observations over the 1995-2009 time

9 period, during which the halogen loading was not changing rapidly, is indicated

10 within each panel.

12 Figure 2 | Time evolution of polar springtime total ozone. Total ozone anomalies

13 relative to the $1964-1978$ reference period for the model simulation with changing

14 ODS abundances (ODS, black), the model simulation with ODS abundances held

15 constant at 1960s values (cODS, blue), ground-based observations (orange), and

16 satellite observations (TOMS ${ }^{48}$, red), for NH polar cap average in March and SH

17 polar cap average in October. The model simulations are not plotted across the ERA-

18 40/ERA-Interim transition (see Supplementary Information). Since the satellite

19 observations only date from 1979, the mean value of the satellite record over the

20 1979-2009 time period is adjusted to match the mean value of the ground-based

21 record.

22 
1 Figure 3 | Time evolution of halogen-induced ozone loss. Annual-mean column

2 ozone difference between the ODS and the cODS simulation (black dots) for the

3 different latitude bands; negative values correspond to ODS-induced loss. The

4 numbers indicate the average differences, with $95 \%$ uncertainties (see

5 Supplementary Information), over 1978-1982, 1996-2002, and 2006-2009. The red

6 curve shows the (inverted) lower stratospheric abundance of Equivalent

7 Stratospheric Chlorine (ESC) 7 at $50 \mathrm{hPa}$, consisting of the sum of inorganic chlorine

8 Cly and 60 times inorganic bromine Bry in the model and representing a measure of

9 stratospheric halogen loading, while the blue curve is a smoothed version of the red

10 curve where a 1-2-1 smoother has been applied 10 times to the annual-mean values.

11 The orange curve shows the Equivalent Effective Stratospheric Chlorine (EESC),

12 which is derived directly from tropospheric halocarbon abundances based on the

13 method of Ref 28, using the same multiplier of 60 for bromine and assuming a mean

14 age of 3 years in the tropics and 5 years in midlatitudes.

16 Figure 4 | Quantification of chemical amplification of total ozone variability.

17 Scatterplots of total ozone anomalies from the ODS and cODS simulation over the

18 period 1995-2009 during which the halogen loading was not changing rapidly, for

19 the latitude bands and months indicated. For midlatitudes, the range of months is

20 chosen to match the period of coherent interannual variability, as defined by the

21 persistence of observed midlatitude total ozone anomalies ${ }^{49}$. For polar regions, the

22 range of months corresponds to the spring season. 
1 Figure 5 | Comparison of stratospheric partial column ozone changes with

2 observations. Modelled monthly mean stratospheric (grey) and tropospheric

3 (black) partial column ozone anomalies with respect to the 1964-1978 reference

4 period for the ODS simulation, averaged over different latitude bands. The

5 midlatitude averages are only taken to 55 degrees latitude because the

6 measurement coverage deteriorates rapidly poleward of that latitude. The model

7 simulations are not plotted across the ERA-40/ERA-Interim transition (see

8 Supplementary Information). The coloured lines and dots indicate stratospheric

9 partial column ozone derived from the SPARC Data Initiative monthly zonal mean

10 ozone climatologies ${ }^{35}$ of LIMS, SAGE I, SAGE II, and MIPAS. The anomalies of the

11 observed data sets are defined such that the mean value of the data matches that

12 from the model during the 2005-2009 (MIPAS) reference period, when the

13 observational sampling is most dense.

\section{Table legend}

17 Table 1 | Quantified long-term ozone changes. Differences are shown between

18 the 1964-1978 and 1996-2002 averages, with declines indicated as negative

19 changes. The percentage changes are with respect to the 1964-1978 climatological

20 mean values. 95\% confidence intervals include uncertainties in the mean value over

21 each time period as well as, for the simulations, the uncertainties in the offset

22 applied between the ERA-40 and ERA-Interim portions of the simulation (see

23 Supplementary Information). 


\section{Figure 1}

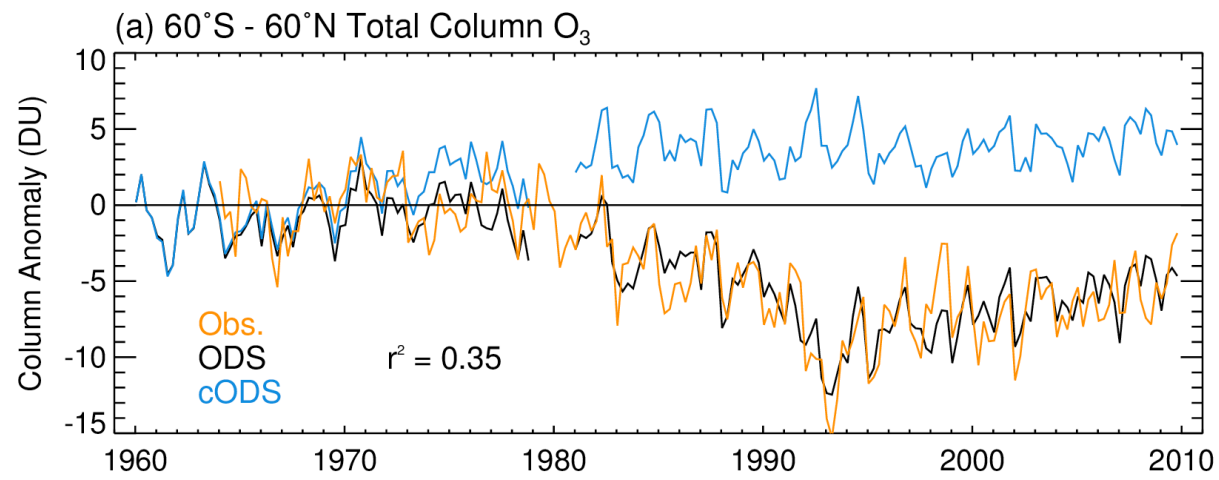

(b) $35-60^{\circ} \mathrm{S}$ Total Column $\mathrm{O}_{3}$

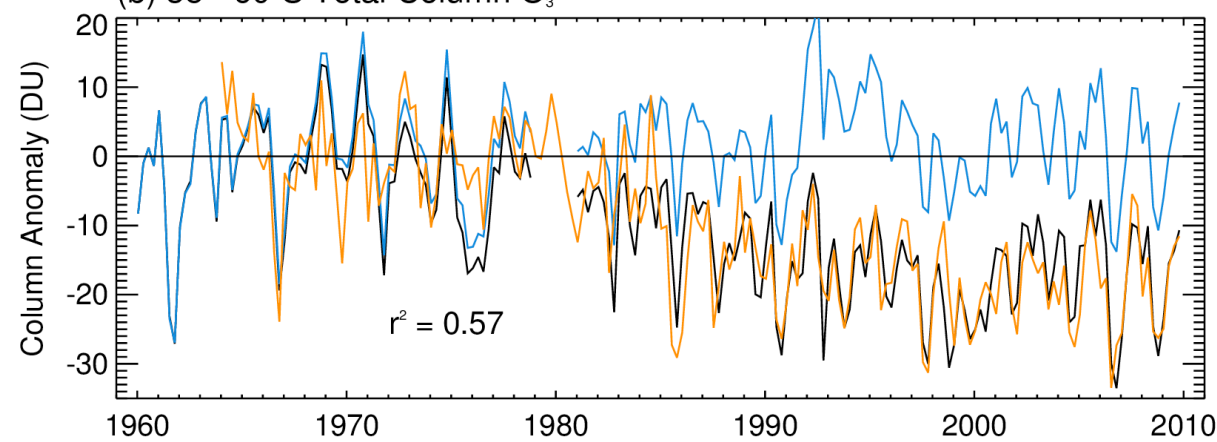

(c) $35-60^{\circ} \mathrm{N}$ Total Column $\mathrm{O}_{3}$

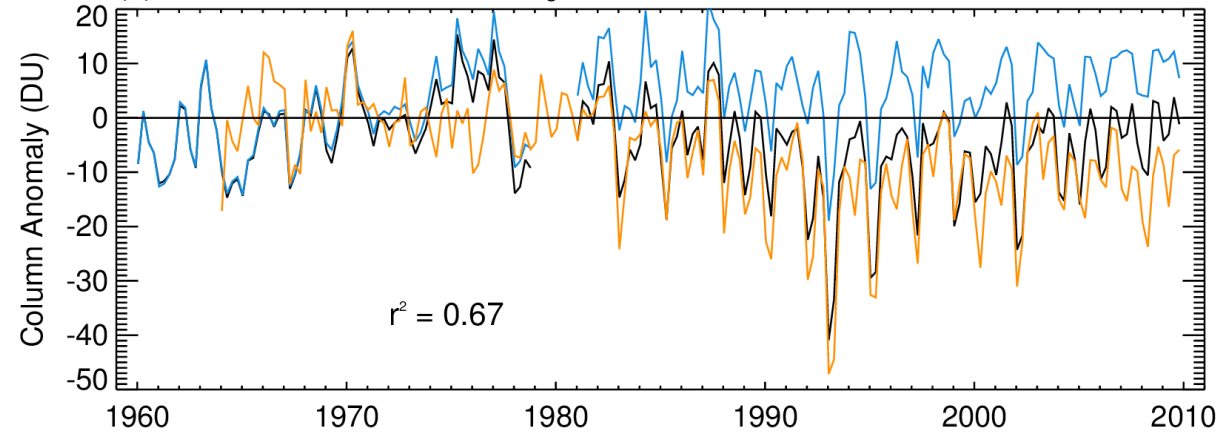

(d) $25^{\circ} \mathrm{N}-25^{\circ} \mathrm{S}$ Total Column $\mathrm{O}_{3}$

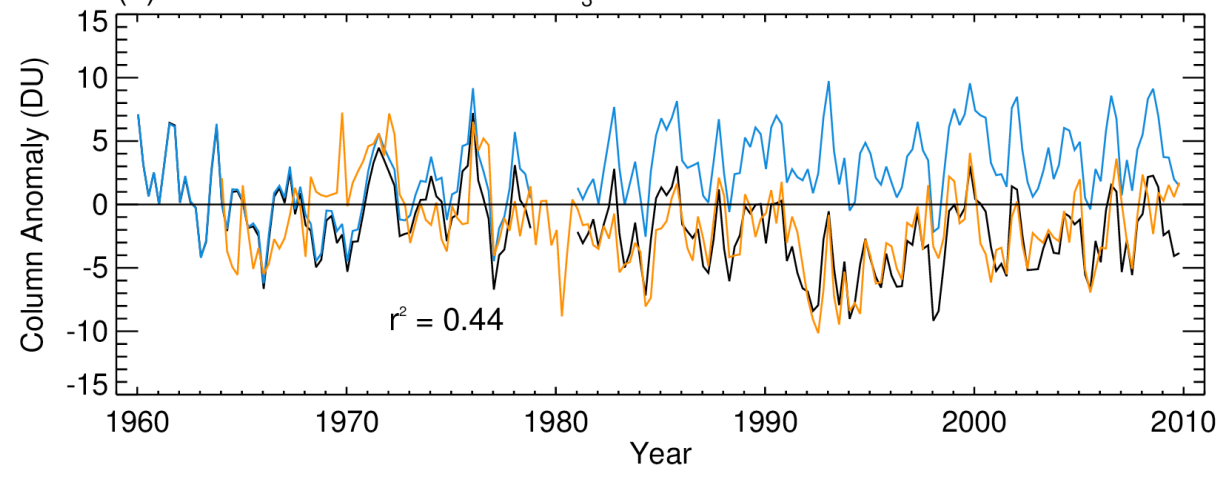




\section{$1 \quad$ Figure 2}
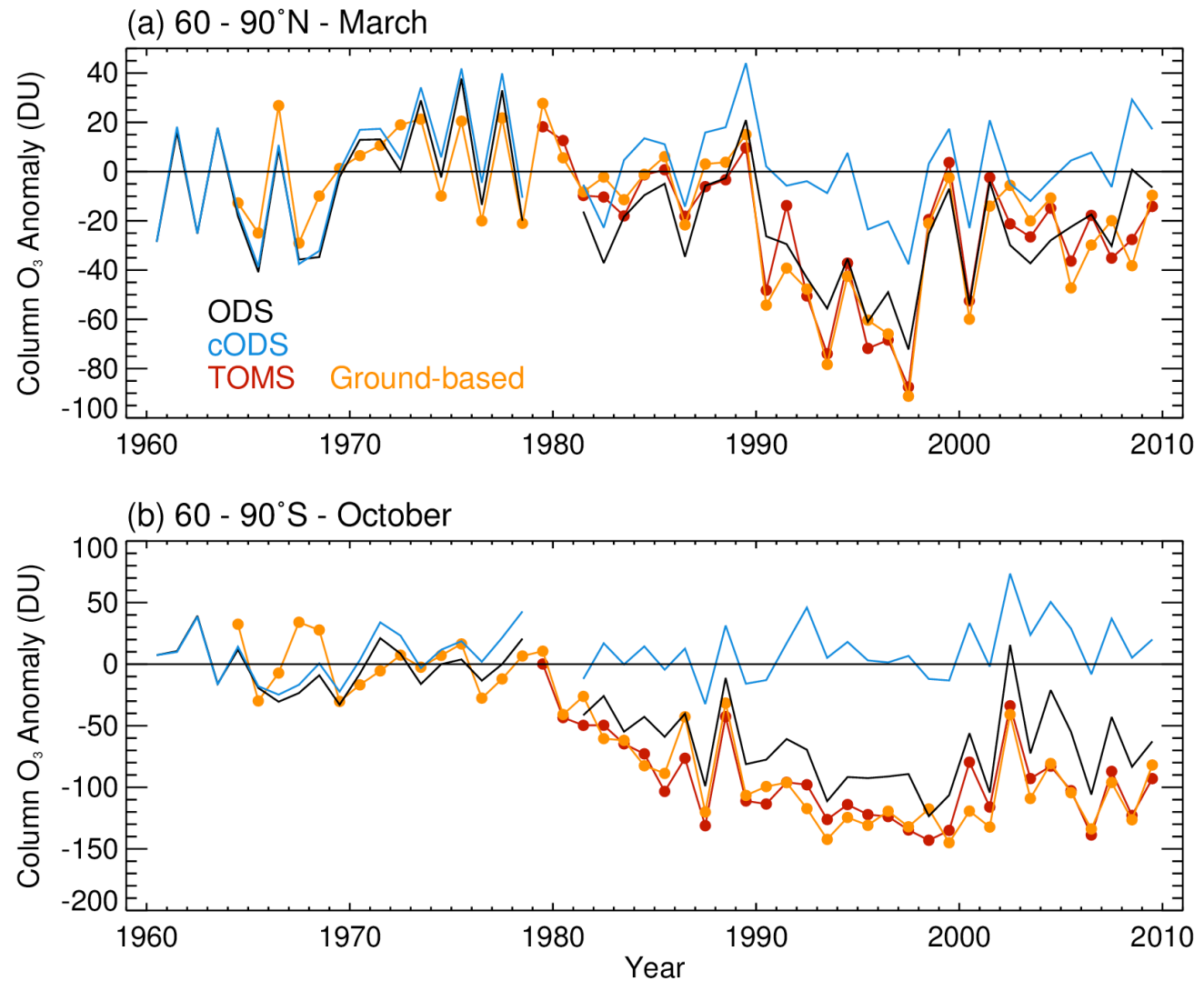
Figure 3

(a) $35-60^{\circ} \mathrm{S}$ ODS-cODS Annual Column $\mathrm{O}_{3}$

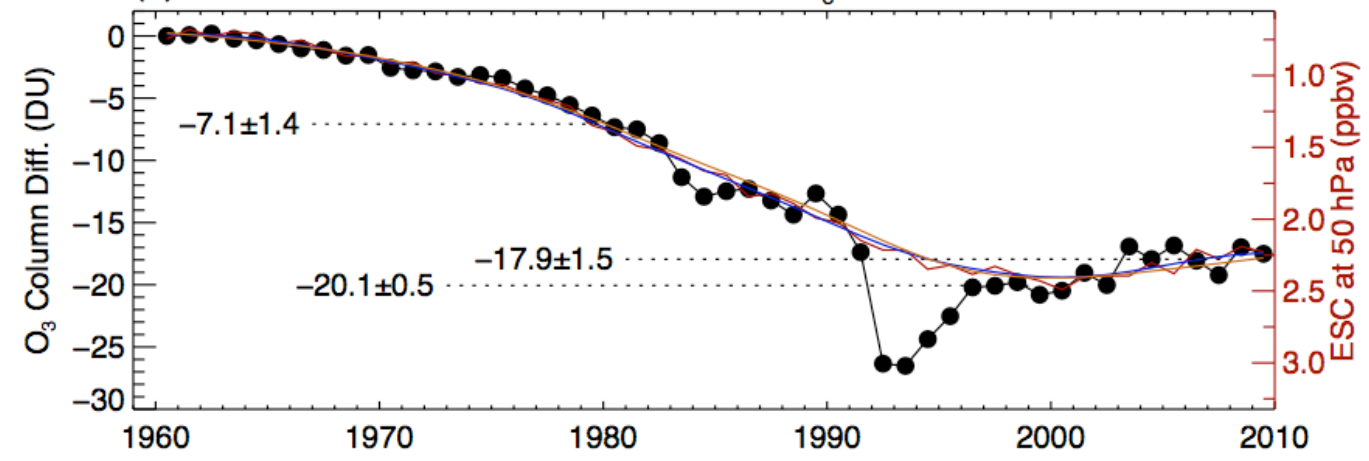

(b) $35-60^{\circ} \mathrm{N}$ ODS-cODS Annual Column $\mathrm{O}_{3}$

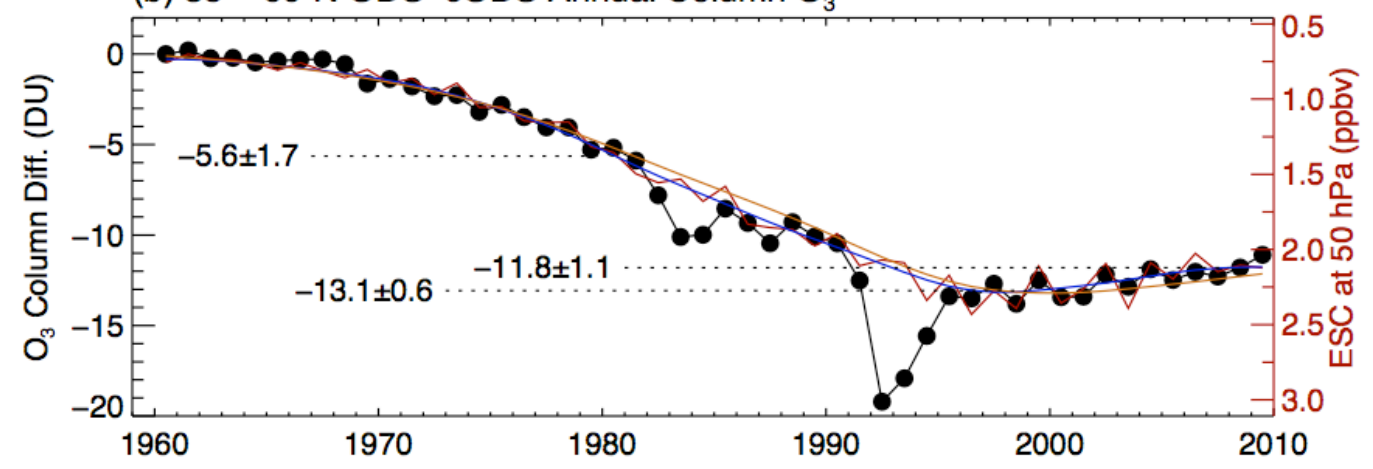

(c) $25^{\circ} \mathrm{S}-25^{\circ} \mathrm{N}$ ODS-cODS Annual Column $\mathrm{O}_{3}$

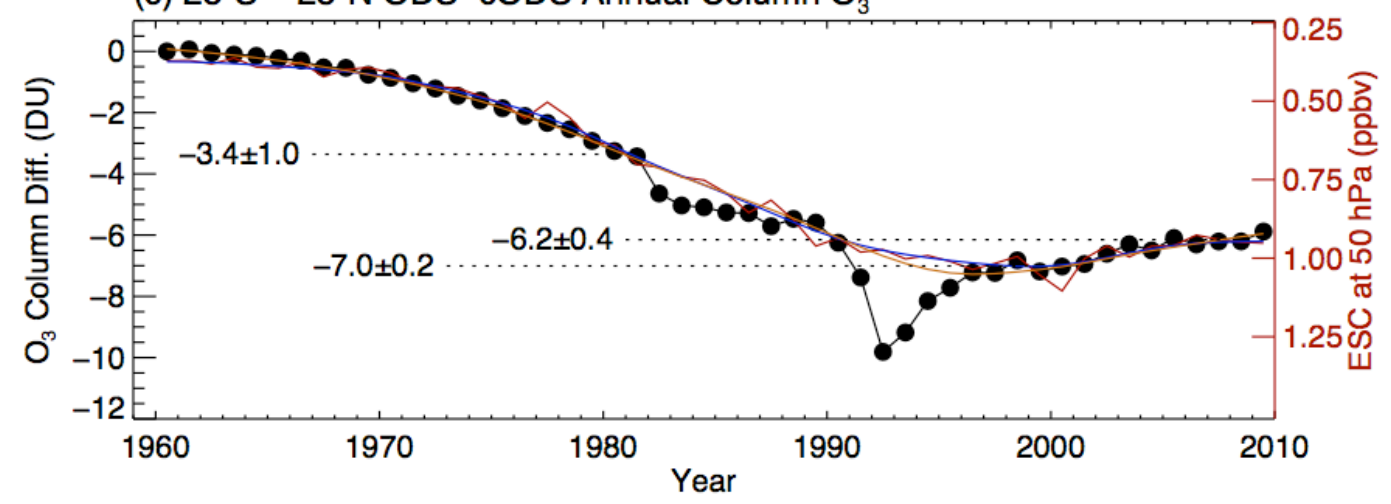


Figure 4

(a) 35 - $60^{\circ} \mathrm{S}$ Nov. - April

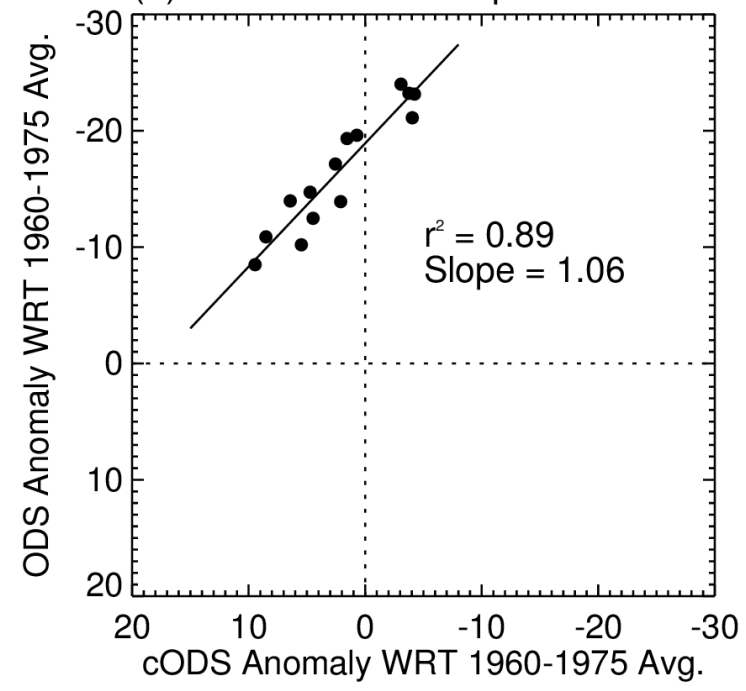

(c) $60-90^{\circ} \mathrm{S}$ Sept. - Nov.

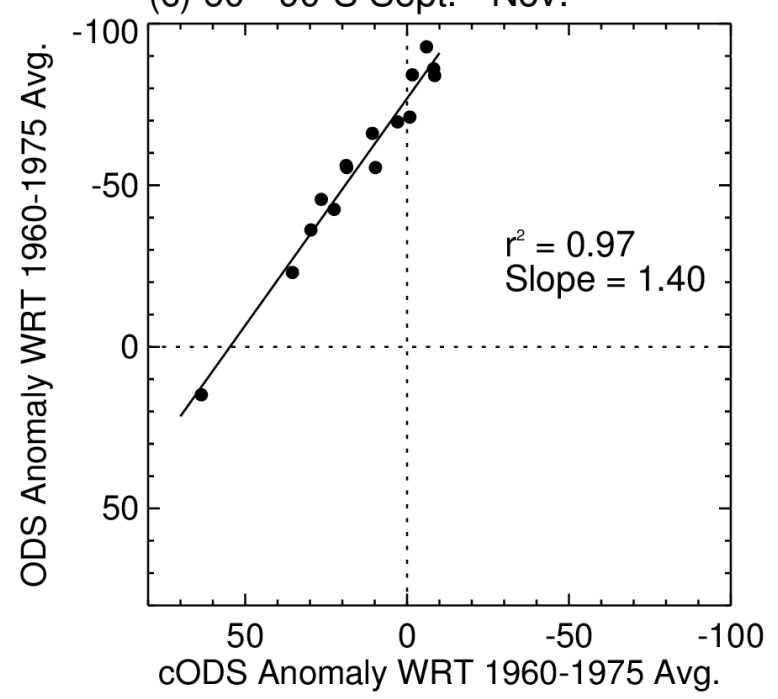

(b) $35-60^{\circ} \mathrm{N}$ March - Oct.

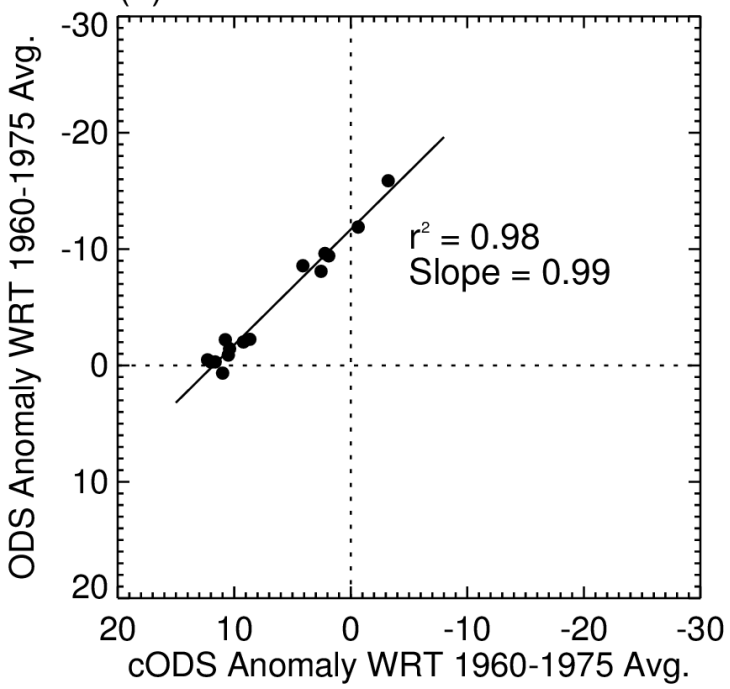

(d) $60-90^{\circ} \mathrm{N}$ March - May

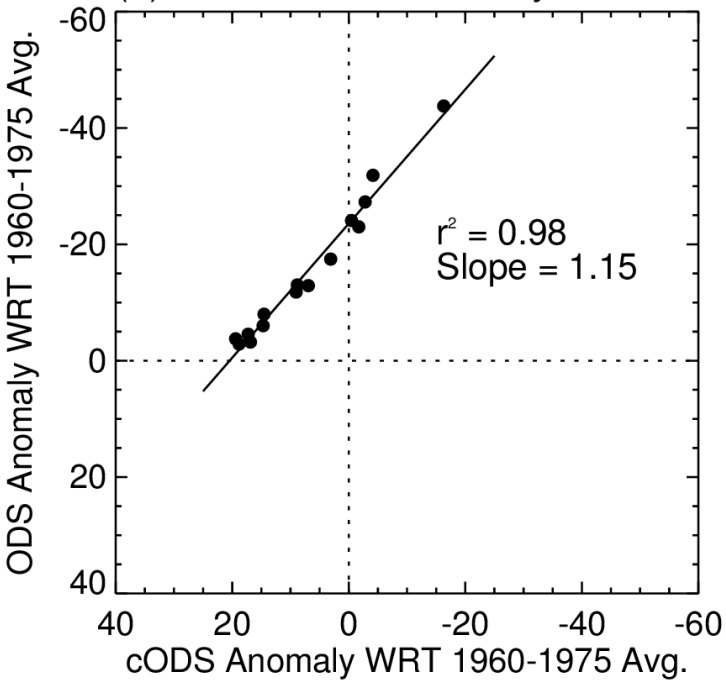


Figure 5

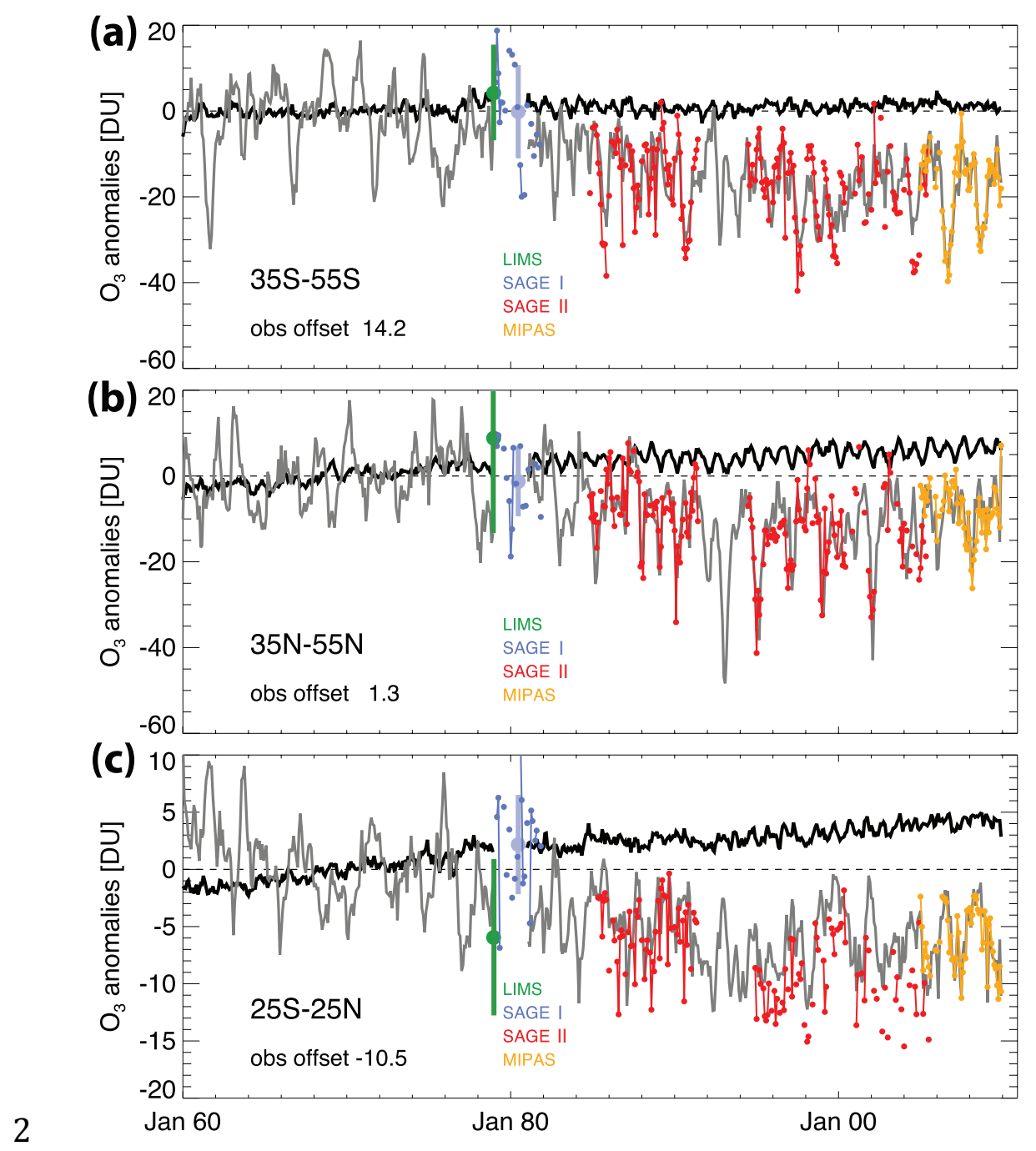


Table 1

\begin{tabular}{|c|c|c|c|c|c|c|c|c|}
\hline & \multicolumn{2}{|c|}{$60^{\circ} \mathrm{S}-60^{\circ} \mathrm{N}$} & \multicolumn{2}{|c|}{$25^{\circ} \mathrm{S}-25^{\circ} \mathrm{N}$} & \multicolumn{2}{|c|}{$35^{\circ} \mathrm{N}-60^{\circ} \mathrm{N}$} & \multicolumn{2}{|c|}{$35^{\circ} \mathrm{S}-60^{\circ} \mathrm{S}$} \\
\hline & $\mathrm{DU}$ & $\%$ & $\mathrm{DU}$ & $\%$ & DU & $\%$ & DU & $\%$ \\
\hline Obs & $\begin{array}{l}-7.03 \\
+/- \\
1.42\end{array}$ & $\begin{array}{l}-2.41 \\
+/- \\
0.49\end{array}$ & $\begin{array}{l}-2.13 \\
+/- \\
2.57\end{array}$ & $\begin{array}{l}-0.81 \\
+/- \\
0.98\end{array}$ & $\begin{array}{l}-11.6 \\
+/- \\
4.11\end{array}$ & $\begin{array}{l}-3.36 \\
+/- \\
1.19\end{array}$ & $\begin{array}{l}-18.8 \\
+/- \\
4.18\end{array}$ & $\begin{array}{l}-5.84 \\
+/- \\
1.30\end{array}$ \\
\hline ODS run & $\begin{array}{l}-6.56 \\
+/- \\
1.13\end{array}$ & $\begin{array}{l}-2.23 \\
+/- \\
0.38\end{array}$ & $\begin{array}{l}-2.34 \\
+/- \\
1.81\end{array}$ & $\begin{array}{l}-0.90 \\
+/- \\
0.70\end{array}$ & $\begin{array}{l}-6.79 \\
+/- \\
4.79\end{array}$ & $\begin{array}{l}-1.97 \\
+/- \\
1.39\end{array}$ & $\begin{array}{l}-18.0 \\
+/- \\
5.87\end{array}$ & $\begin{array}{l}-5.22 \\
+/- \\
1.70\end{array}$ \\
\hline ODS strat & $\begin{array}{l}-9.45 \\
+/- \\
0.95\end{array}$ & $\begin{array}{l}-3.56 \\
+/- \\
0.36\end{array}$ & $\begin{array}{l}-5.24 \\
+/- \\
1.71\end{array}$ & $\begin{array}{l}-2.23 \\
+/- \\
0.73\end{array}$ & $\begin{array}{l}-11.6 \\
+/- \\
4.34\end{array}$ & $\begin{array}{l}-3.74 \\
+/- \\
1.49\end{array}$ & $\begin{array}{l}-18.6 \\
+/- \\
5.23\end{array}$ & $\begin{array}{l}-5.91 \\
+/- \\
1.66\end{array}$ \\
\hline ODS trop & $\begin{array}{l}+2.89 \\
+/- \\
0.78\end{array}$ & $\begin{array}{l}+9.98 \\
+/- \\
2.69\end{array}$ & $\begin{array}{l}+2.91 \\
+/- \\
0.69\end{array}$ & $\begin{array}{l}+12.0 \\
+/- \\
2.84\end{array}$ & $\begin{array}{l}+4.82 \\
+/- \\
1.47\end{array}$ & $\begin{array}{l}+13.7 \\
+/- \\
4.18\end{array}$ & $\begin{array}{l}+0.57 \\
+/- \\
1.19\end{array}$ & $\begin{array}{l}+1.88 \\
+/- \\
3.90\end{array}$ \\
\hline cODS run & $\begin{array}{l}+2.72 \\
+/- \\
1.15\end{array}$ & $\begin{array}{l}+0.92 \\
+/- \\
0.39\end{array}$ & $\begin{array}{l}+3.50 \\
+/- \\
1.86\end{array}$ & $\begin{array}{l}+1.34 \\
+/- \\
0.71\end{array}$ & $\begin{array}{l}+4.35 \\
+/- \\
5.12\end{array}$ & $\begin{array}{l}+1.25 \\
+/- \\
1.47\end{array}$ & $\begin{array}{l}-0.54 \\
+/- \\
5.34\end{array}$ & $\begin{array}{l}-0.15 \\
+/- \\
1.54\end{array}$ \\
\hline cODS strat & $\begin{array}{l}-1.45 \\
+/- \\
0.99\end{array}$ & $\begin{array}{l}-0.54 \\
+/- \\
0.37\end{array}$ & $\begin{array}{l}-0.27 \\
+/- \\
1.78\end{array}$ & $\begin{array}{l}-0.11 \\
+/- \\
0.75\end{array}$ & $\begin{array}{l}-1.45 \\
+/- \\
4.95\end{array}$ & $\begin{array}{l}-0.46 \\
+/- \\
1.59\end{array}$ & $\begin{array}{l}-3.66 \\
+/- \\
4.77\end{array}$ & $\begin{array}{l}-1.15 \\
+/- \\
1.51\end{array}$ \\
\hline cODS trop & $\begin{array}{l}+4.17 \\
+/- \\
0.82\end{array}$ & $\begin{array}{l}+14.3 \\
+/- \\
2.80\end{array}$ & $\begin{array}{l}+3.77 \\
+/- \\
0.71\end{array}$ & $\begin{array}{l}+15.5 \\
+/- \\
2.93\end{array}$ & $\begin{array}{l}+5.79 \\
+/- \\
1.50\end{array}$ & $\begin{array}{l}16.4 \\
+/- \\
4.26\end{array}$ & $\begin{array}{l}+3.12 \\
+/- \\
1.20\end{array}$ & $\begin{array}{l}+10.2 \\
+/- \\
3.91\end{array}$ \\
\hline ODS-cODS & $\begin{array}{l}-9.28 \\
+/- \\
0.59\end{array}$ & $\begin{array}{l}-3.15 \\
+/- \\
0.20\end{array}$ & $\begin{array}{l}-5.84 \\
+/- \\
0.46\end{array}$ & $\begin{array}{l}-1.98 \\
+/- \\
0.16\end{array}$ & $\begin{array}{l}-11.1 \\
+/- \\
0.88\end{array}$ & $\begin{array}{l}-3.78 \\
+/- \\
0.30\end{array}$ & $\begin{array}{l}-17.5 \\
+/- \\
0.94\end{array}$ & $\begin{array}{l}-5.94 \\
+/- \\
0.32\end{array}$ \\
\hline $\begin{array}{l}\text { ODS-cODS } \\
\text { strat }\end{array}$ & $\begin{array}{l}-8.00 \\
+/- \\
0.57\end{array}$ & $\begin{array}{l}-3.02 \\
+/- \\
0.21\end{array}$ & $\begin{array}{l}-4.98 \\
+/- \\
0.44\end{array}$ & $\begin{array}{l}-1.88 \\
+/- \\
0.17\end{array}$ & $\begin{array}{l}-10.2 \\
+/- \\
0.86\end{array}$ & $\begin{array}{l}-3.83 \\
+/- \\
0.32\end{array}$ & $\begin{array}{l}-14.9 \\
+/- \\
0.88\end{array}$ & $\begin{array}{l}-5.62 \\
+/- \\
0.33\end{array}$ \\
\hline ODS-cODS trop & $\begin{array}{l}-1.28 \\
+/- \\
0.05\end{array}$ & $\begin{array}{l}-4.42 \\
+/- \\
0.19\end{array}$ & $\begin{array}{l}-0.86 \\
+/- \\
0.04\end{array}$ & $\begin{array}{l}-2.96 \\
+/- \\
0.14\end{array}$ & $\begin{array}{l}-0.97 \\
+/- \\
0.05\end{array}$ & $\begin{array}{l}-3.35 \\
+/- \\
0.18\end{array}$ & $\begin{array}{l}-2.55 \\
+/- \\
0.14\end{array}$ & $\begin{array}{l}-8.78 \\
+/- \\
0.48\end{array}$ \\
\hline
\end{tabular}


3 Reconciling halogen-induced ozone loss with the observed total ozone record

5 T.G. Shepherd, D.A. Plummer, J.F. Scinocca, M.I. Hegglin, V.E. Fioletov, M.C. Reader, E.

6 Remsberg, T. von Clarmann, H.J. Wang

8 Bridging the ERA-40/ERA-Interim transition. For the model simulations, there is

9 a potential inhomogeneity between the ERA-40 and ERA-Interim portions of the

10 record which if not corrected could introduce spurious long-term changes in the

11 modelled ozone. The cODS simulation is used to identify the effect of this

12 inhomogeneity because the stratospheric ozone changes in the cODS simulation are

13 relatively small; since the inhomogeneity affects both the cODS and ODS simulations

14 in the same way (as confirmed by the smoothness of the ODS-cODS differences

15 across the 1979 transition, see Figure 3), adjustments made to the cODS simulation

16 can also be applied to the ODS simulation, producing a homogeneous record. Figure

17 S1 shows the stratospheric and tropospheric ozone timeseries for various regions.

18 For the stratospheric timeseries, there are no trends evident in the cODS simulation

19 during either the ERA-40 or ERA-Interim portions of the record, thus no trend is

20 assumed between them and a constant offset is applied to the ERA-Interim portion

21 of the record so that the average monthly mean values over the 1964-1978 and

22 1981-1995 periods (shown by the horizontal lines, with uncertainties) match. It is

23 clear from the figure that determining the offset from the ODS simulation would be 
1 far more difficult because of the ODS-induced trends. For the tropospheric cODS

2 timeseries, trends are evident during both parts of the record (consistent with

3 changes in tropospheric emissions of ozone precursors), so a constant offset to the

4 ERA-Interim portion of the record is applied such that the linear trends in the

5 monthly mean values over the 1960-1978 and 1981-2009 periods (shown by the

6 straight lines, with uncertainties) meet in 1980. The uncertainties in these offsets

7 are propagated through to the uncertainties in the long-term changes shown in

8 Table 1 . Note that the offsets only affect ozone changes between the pre-1979 and

9 post-1979 periods, not changes within either period; nor do they affect the cODS-

10 ODS differences. A transition period of a few years is evident in the raw timeseries

11 following the switch to ERA-Interim in 1979, hence the adjusted timeseries shown

12 in Figures 1, 2 and 5 are not plotted between 1979 and 1981.

14 Definitions of confidence intervals. The $95 \%$ confidence intervals (CIs) of the

15 total column ozone differences were calculated from the standard error of the

16 means assuming the errors are distributed as Student's t. Since the differences in

17 total column ozone implicitly contain the offsets used to merge the ERA-40 and ERA-

18 Interim periods of the simulation, the standard errors of the offsets were added in

19 quadrature to the standard errors of the means. The standard errors of the offsets

20 were, in turn, calculated from the standard errors of the mean stratospheric column

21 of the cODS experiment over 1964-1978 and 1981-1995 and the standard error on

22 the linear least-squares fit to the tropospheric ozone column at 1980. The standard

23 error in the linear regression of the tropospheric column accounts for the 
1 extrapolation of the 1960-1978 linear trend forward to 1980 and the extrapolation

2 backwards to 1980 of the linear trend calculated over 1981-2009. Noting that the

3 mean over the 1964-1978 period appears as a term both in the calculation of the

4 ERA-40/ERA-Interim offset and in the 1964-1978 to 1996-2002 differences given in

5 Table 1, and that the interannual variability in the ODS and cODS experiments was

6 essentially identical over this period, the contribution of the standard error of the

$7 \quad$ 1964-1978 mean cancelled out in the calculation of the CI for the stratospheric and

8 total column ozone changes. The calculation of the $95 \% \mathrm{CI}$ for the stratospheric

9 column differences was verified by comparing the CI with that derived by a Monte

10 Carlo method where the data for 1964-1978, 1981-1995 and 1996-2002 were

11 resampled with replacement 10000 times and the ERA-40/ERA-Interim offset and

12 column differences were recalculated for each sample. The effective sample size for

13 all quantities was adjusted to account for the lag-1 autocorrelation.

14

15 
1 Figure S1 | Determination of offsets between ERA-40 and ERA-Interim periods.

2 Original time series of cODS (black) and ODS (red) simulations for each of the four

3 latitude bands (35-60N, 25S-25N, 35-60S, 60S-60N), for both tropospheric and

4 stratospheric ozone. Linear trends in the cODS simulation over the periods 1964-

51978 and 1981-1995 are indicated within each panel. Within each subregion, the

6 stratospheric trends are not statistically distinguishable from zero, hence are

7 assumed to be zero and the mean values over each period are computed (shown as

8 black horizontal lines with 95\% confidence intervals); their difference determines

9 the offset, which is indicated within each panel. Non-zero tropospheric trends are

10 clearly present, so in this case a linear fit is made to each time period (straight black

11 lines with 95\% confidence intervals); the difference between those fits in 1980

12 determines the offset, which is indicated within each panel. 
(a) $35-60^{\circ} \mathrm{N}$ Annual Avg. Stratospheric $\mathrm{O}_{3}$ Column

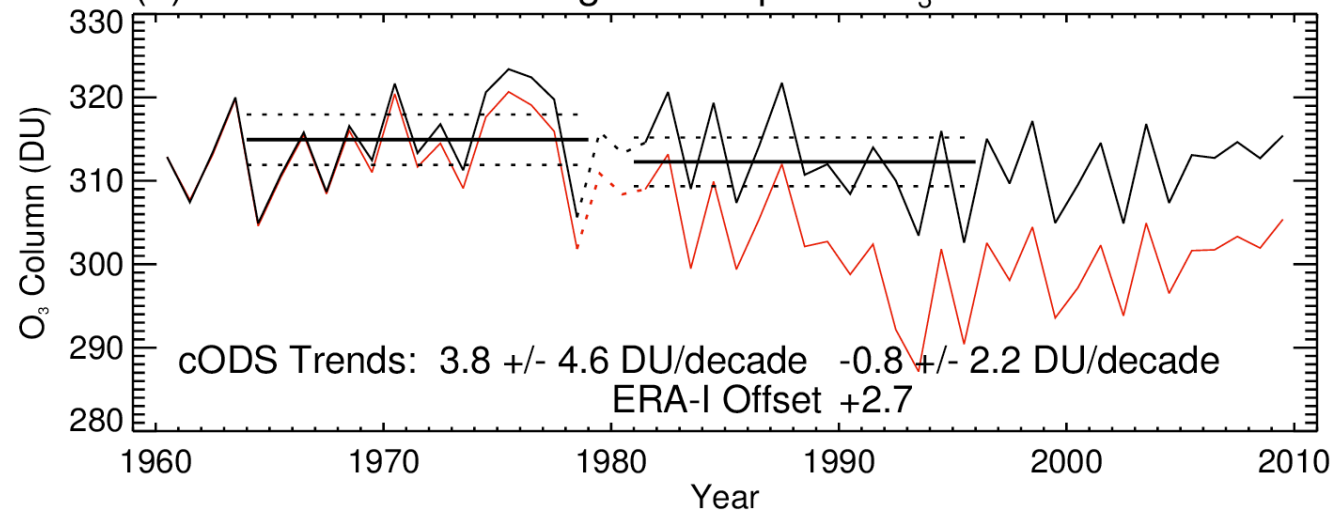

(b) $35-60^{\circ} \mathrm{N}$ Annual Avg. Tropo. $\mathrm{O}_{3}$ Column

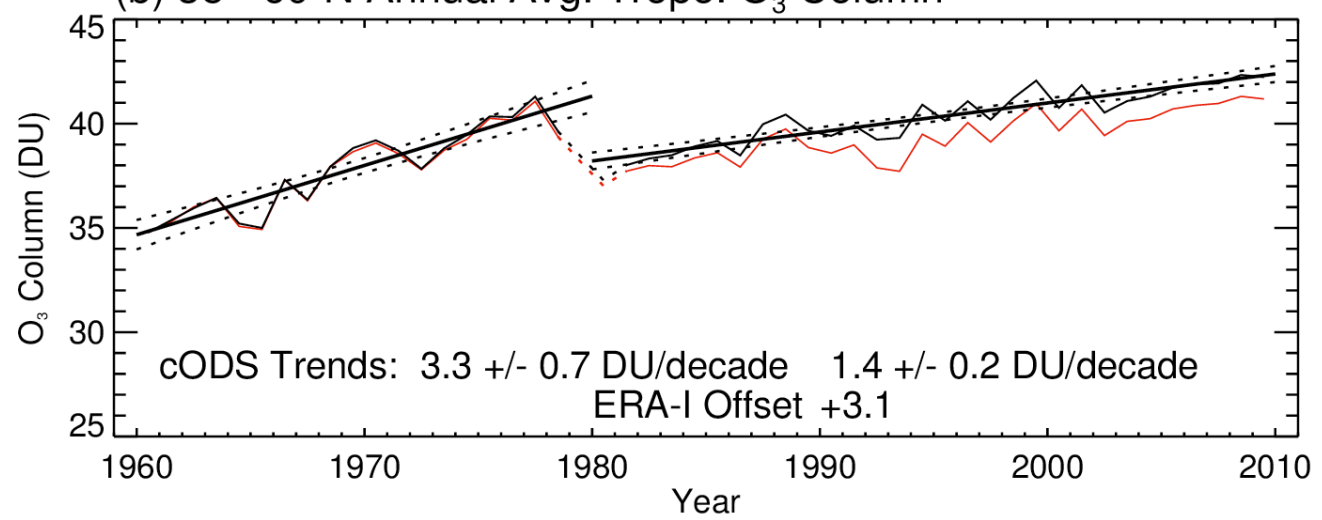

(c) $25^{\circ} \mathrm{S}-25^{\circ} \mathrm{N}$ Annual Avg. Stratospheric $\mathrm{O}_{3}$ Column

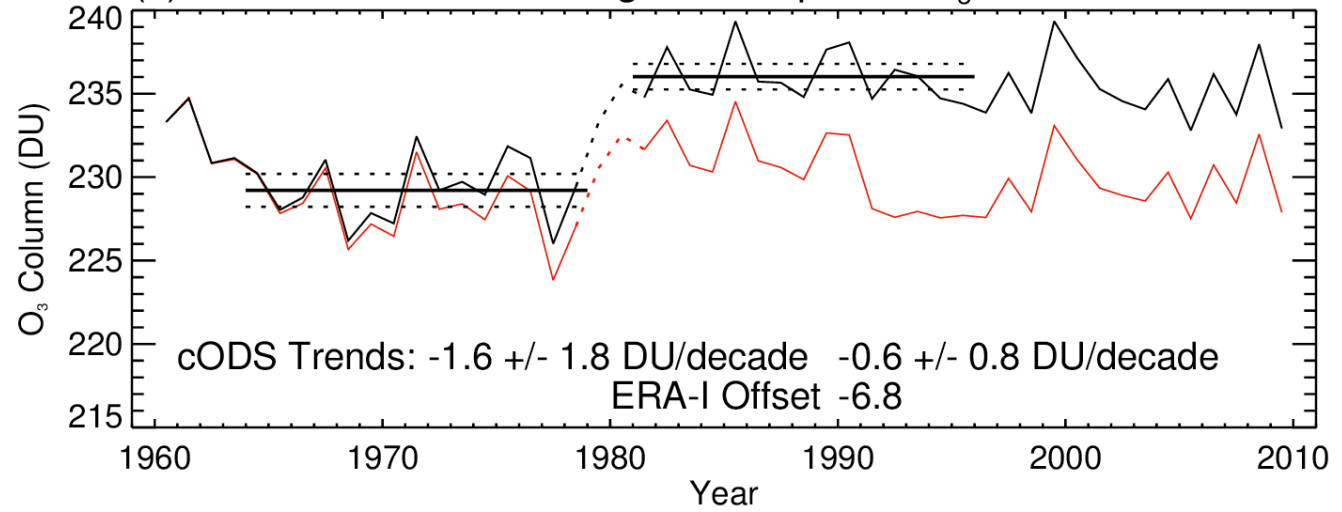

(d) $25^{\circ} \mathrm{S}-25^{\circ} \mathrm{N}$ Annual Avg. Tropo. $\mathrm{O}_{3}$ Column

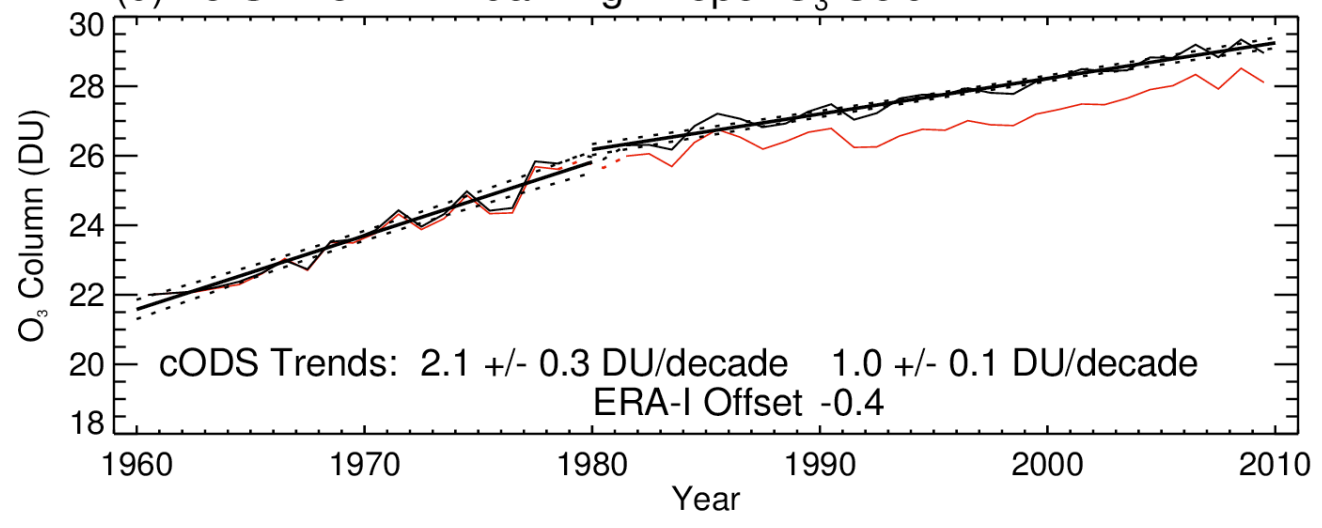


(e) 35 - $60^{\circ} \mathrm{S}$ Annual Avg. Stratospheric $\mathrm{O}_{3}$ Column
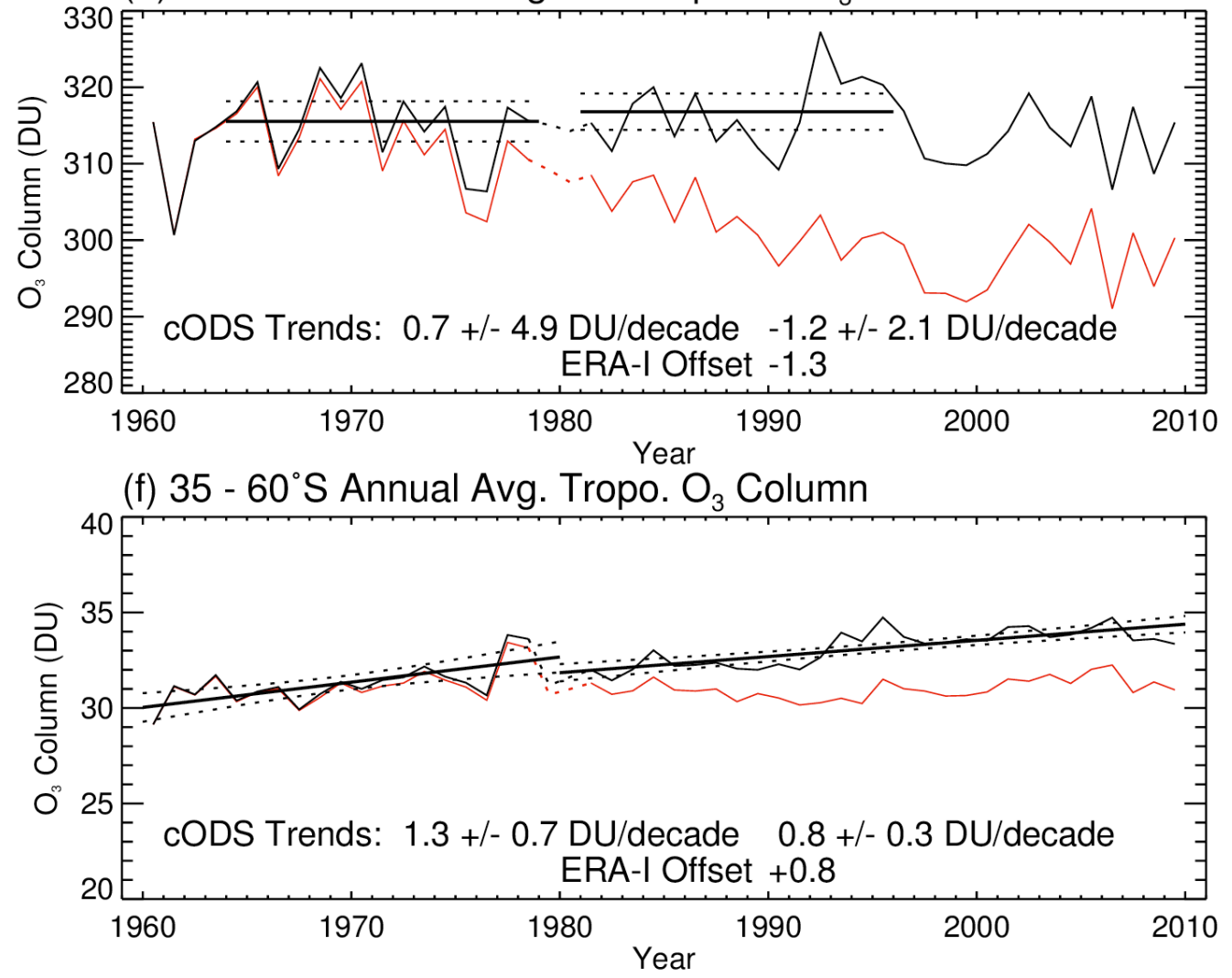

(g) $60^{\circ} \mathrm{N}-60^{\circ} \mathrm{S}$ Annual Avg. Stratospheric $\mathrm{O}_{3}$ Column

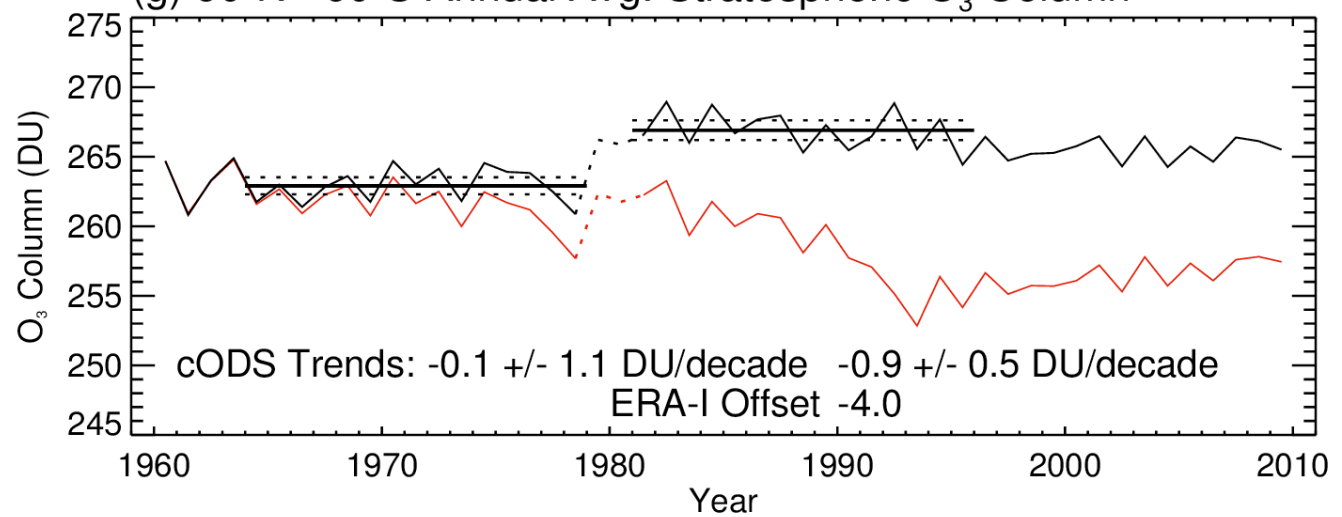

(h) $60^{\circ} \mathrm{N}-60^{\circ} \mathrm{S}$ Annual Avg. Tropo. $\mathrm{O}_{3}$ Column

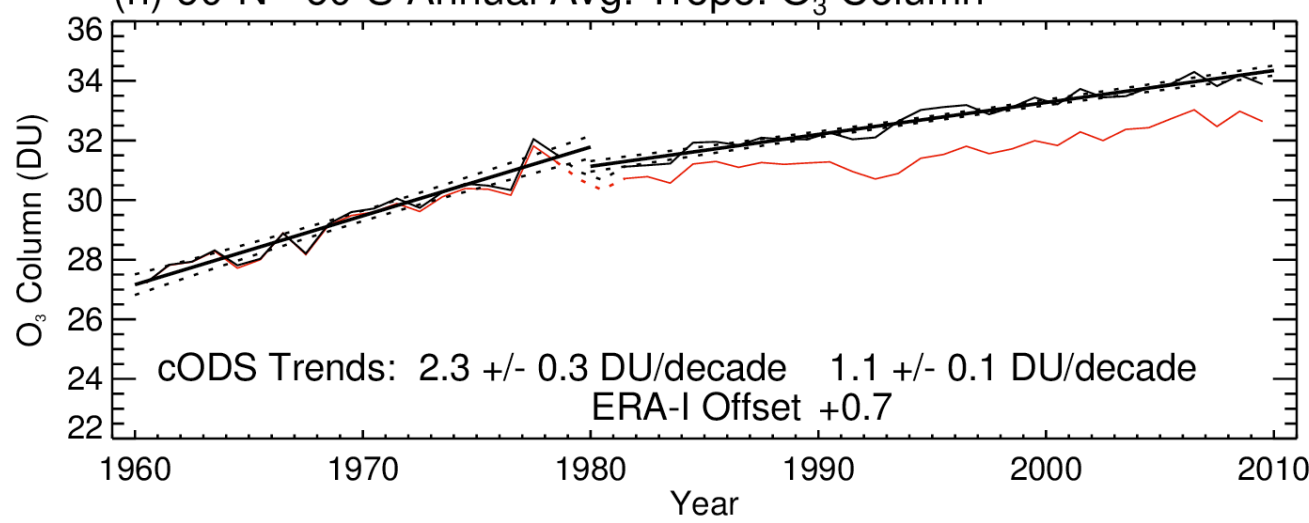

